\title{
An investigation into the use of activated and non-activated papain in routine rhesus blood grouping
}

\author{
G. C. B. WINTER ${ }^{1}$ AND B. E. WRATTEN
}

From the R.A.F. Institute of Pathology and Tropical Medicine, Halton, Aylesbury, Bucks.

SYNOPSIS The activities of three commercial products of papain were compared as supplied and after activation, and when used in the enzyme-serum method for rhesus (D) grouping. Certain dangers in activation became apparent, and accurate determination of the proportions of papain to anti-D appeared more important than indiscriminate activation without reference to the initial enzyme activity. A technique for assessing these proportions is described.

Low (1955) described a method for routine rhesus grouping using papain, previously activated with cystein, mixed with incomplete anti-D serum. This method was being used to group the blood of Royal Air Force recruits when it was seen that the accidental omission of the activation had no apparent ill effects. The particular papain in use (Hopkin and Williams Papain 6458) gave identical results in 2,000 tests, with no discrepancies, before and after activation, so this investigation was made to determine the need or otherwise for activation. It comprised five experiments in which three commercial preparations of papain were compared before and after activation, using $1 \%$ solutions. Their preparation, described in the Appendix, was followed by an estimation of the activity of each papain (experiment 1) with the milk clotting method of Balls and Hoover (1937). The results are shown in Table I.

TABLE I

RESULTS IN EXPERIMENT 1

\section{Papain}

Average Time/3 Readings (min. sec.)

Activated B.D.H.

Non-activated B.D.H.

Activated Hopkin and Williams

Non-activated Hopkin and Williams

Activated Merck

Non-activated Merck

$\begin{array}{rr}0 & 24 \\ 0 & 38 \\ 0 & 40 \\ 2 & 16 \\ 1 & 0 \\ 14 & 0\end{array}$

EXPERIMENT 2

Experiment 2 is an example of the titration of a high-titre incomplete anti-D serum using the albumin and papain methods.

${ }^{1}$ Present address: Department of Public Health, Tower Hill, Bristol 2.

Received for publication 18 April 1962.
REAGENTS $1 \%$ Activated and non-activated papains were used prepared as described in the Appendix.

ANTI-D This was the M.R.C. Blood Group Reference Laboratory Serum, D+T 1958, high-titre incomplete anti-D.

ERYTHROCYTES Cells from two group $O$ donors of probable rhesus genotypes $\mathrm{CDe} / \mathrm{cDE}$ and cde/cde were used.

From blood taken by venepuncture $1 \mathrm{ml}$. volumes were immediately suspended in saline; the cells were washed three times and finally suspended in $19 \mathrm{ml}$. of saline to give cell suspensions of approximately $2.5 \%$. Each blood sample used had normal haemoglobin and P.C.V. levels and gave a negative direct Coombs reaction.

METHOD Serial dilutions of the anti-D from 1 in 1 to 1 in 2,048 were made in saline and also in $A B$ serum. $A$ preliminary albumin replacement (Dunsford and Bowley, 1955) was performed with $\mathrm{CDe} / \mathrm{cDE}$ and cde/cde cells. Next enzyme-serum mixtures were made up in the proportion of 3:1 for each of the six types of papain at each dilution of the anti-D in saline and $A B$ serum. One volume of cde/cde cells was then added to one volume of each mixture, repeated with $\mathrm{CDe} / \mathrm{cDE}$ cells, and the tubes incubated at $37^{\circ} \mathrm{C}$. for one hour. In all the experiments the results were first read macroscopically and then microscopically and recorded thus:-

++++ Solid agglutinate, no free cells; +++ several large agglutinates, small proportion of free cells present; ++ naked-eye agglutinates, moderate proportion of free cells present; +agglutinates visible only by microscope (2/3 objective), large proportion of free cells present. Negatives were recorded by a blank space when $100 \%$ free cells were found.

RESULTS With cde/cde cells, after diluting the serum with saline, false positives occur, especially with 
TABLE II

RESULTS IN EXPERIMENT 2

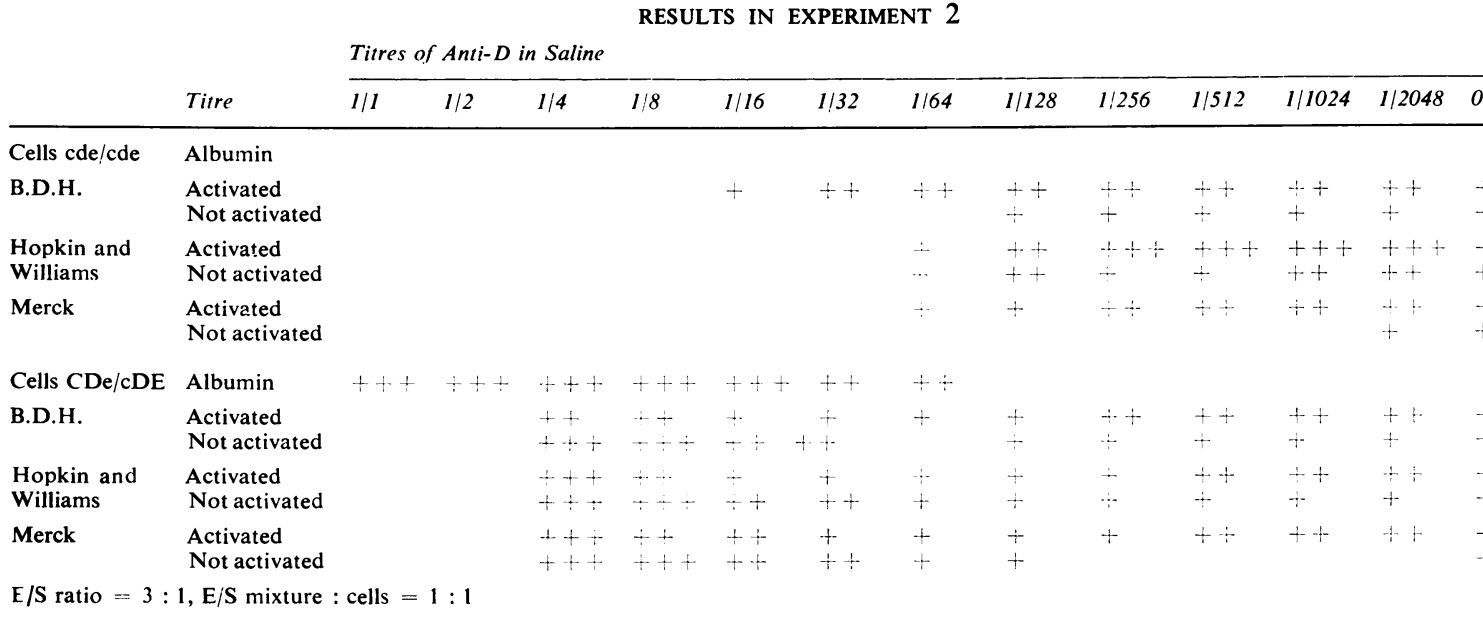

TABLE III

RESULTS IN EXPERIMENT 3

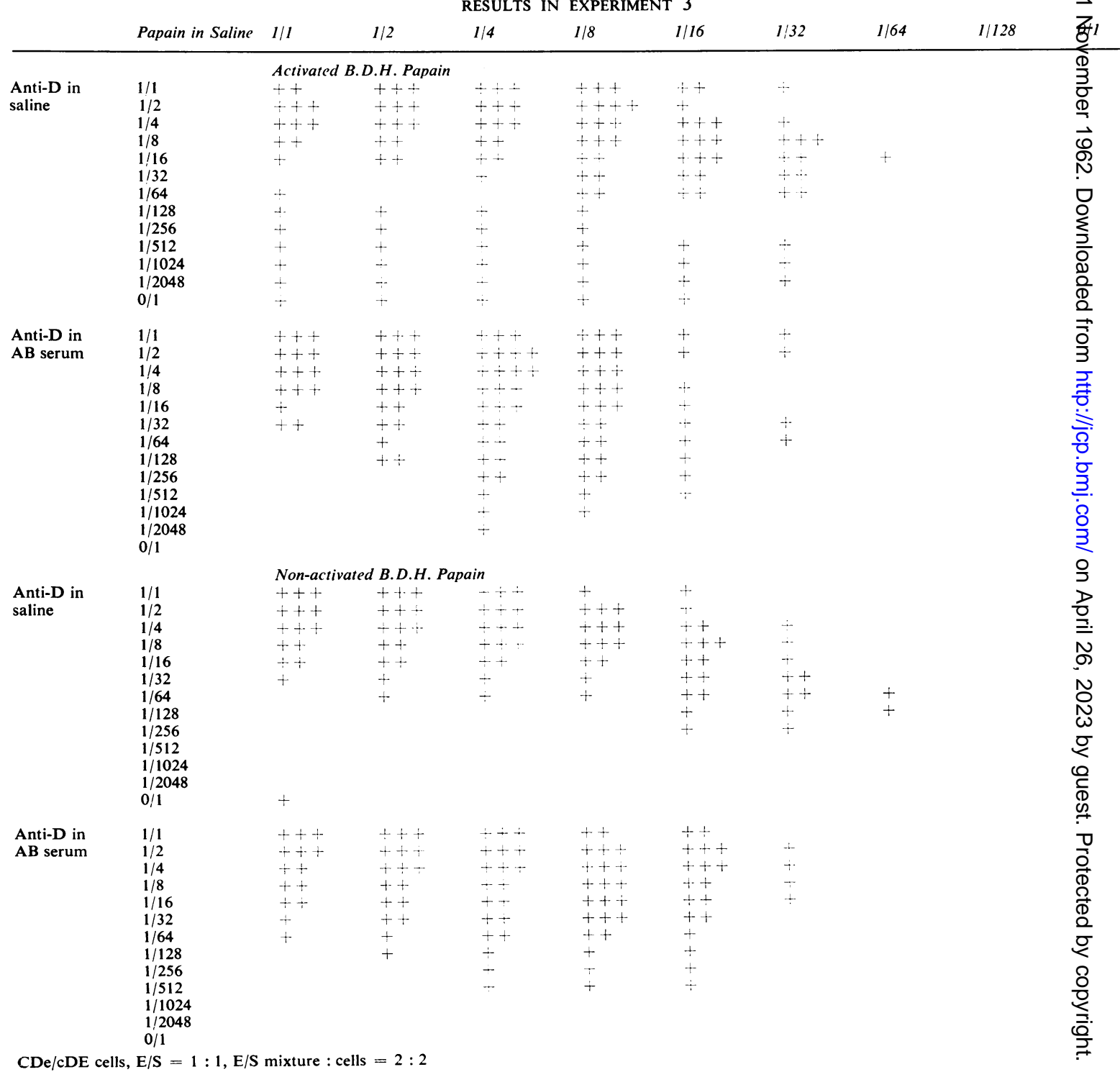




$$
\begin{aligned}
& ++ \\
& + \\
& +++ \\
& ++ \\
& ++ \\
& + \\
& ++ \\
& + \\
& ++ \\
& + \\
& +
\end{aligned}
$$

\begin{tabular}{|c|c|c|c|c|c|}
\hline $1 / 1$ & $1 / 2$ & $1 / 4$ & $1 / 8$ & $1 / 16$ & $1 / 32$ \\
\hline $\begin{array}{l}\text { Activated } \\
+++ \\
+++ \\
+++ \\
+++ \\
++ \\
+ \\
+ \\
+ \\
+ \\
+ \\
++ \\
++ \\
+\end{array}$ & $\begin{array}{l}\text { Hopkin ind } \\
++++ \\
+++ \\
+++ \\
+++ \\
+++ \\
++ \\
++ \\
+ \\
+ \\
++ \\
++ \\
++ \\
+\end{array}$ & $\begin{array}{l}\text { Williams } P \\
++++ \\
++++ \\
++++ \\
+++ \\
++++ \\
+++ \\
++ \\
+ \\
+ \\
++ \\
++ \\
++ \\
+\end{array}$ & $\begin{array}{l}\text { apain } \\
+ \\
+++ \\
++++ \\
++++ \\
+++ \\
+++ \\
+++ \\
+ \\
+ \\
+ \\
+ \\
++ \\
+\end{array}$ & $\begin{array}{l}++ \\
+++ \\
+++ \\
+++ \\
+++ \\
++ \\
+\end{array}$ & $\begin{array}{l}+ \\
++ \\
+\end{array}$ \\
\hline $\begin{array}{l}++++ \\
+++ \\
++ \\
++ \\
+ \\
+ \\
+ \\
+\end{array}$ & $\begin{array}{l}++++ \\
+++ \\
+++ \\
+++ \\
++ \\
++ \\
++ \\
+\end{array}$ & $\begin{array}{l}++++ \\
+++ \\
+++ \\
++ \\
++ \\
++ \\
++ \\
++ \\
+\end{array}$ & $\begin{array}{l}++ \\
++ \\
++ \\
+++ \\
++ \\
++ \\
++ \\
+ \\
+\end{array}$ & $\begin{array}{l}+ \\
++ \\
++ \\
++ \\
++ \\
+ \\
+\end{array}$ & $\begin{array}{l}++ \\
+\end{array}$ \\
\hline
\end{tabular}

\begin{tabular}{|c|c|c|c|c|}
\hline \multicolumn{5}{|c|}{ Activated Merck Papain } \\
\hline$+t+$ & +++ & ++ & ++ & + \\
\hline++ & +++ & ++ & + & \\
\hline++ & +++ & ++ & + & \\
\hline++ & ++ & ++ & + & \\
\hline+ & ++ & ++ & + & \\
\hline+ & + & + & + & \\
\hline+ & + & + & + & \\
\hline++ & + & & & \\
\hline++ & + & + & & \\
\hline++ & ++ & ++ & & \\
\hline++ & ++ & ++ & & \\
\hline++ & ++ & ++ & ++ & \\
\hline++ & ++ & ++ & ++ & + \\
\hline++ & ++ & ++ & + & \\
\hline++ & ++ & ++ & + & \\
\hline++ & ++ & + & + & \\
\hline++ & $+t$ & + & + & \\
\hline $\begin{array}{l}+ \\
+\end{array}$ & $\begin{array}{l}+ \\
+\end{array}$ & $\begin{array}{l}++ \\
+\end{array}$ & & \\
\hline
\end{tabular}

TABLE III-continued RESULTS IN EXPERIMENT 3

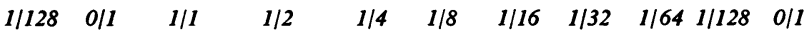

Non-activated Hopkin and Williams Papain

$\begin{array}{llll}\text { Non-activated Hopkin and Williams Papa } \\ ++++ & ++++ & +++ & ++ \\ ++++ & ++++ & +++ & ++ \\ +++ & +++ & +++ & ++ \\ +++ & +++ & +++ & + \\ ++ & ++ & ++ & ++ \\ ++ & ++ & + & + \\ + & + & & \end{array}$

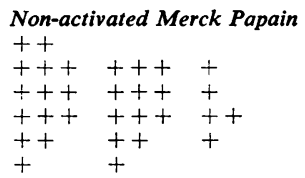

.

+
+
+ $\begin{array}{lll}1 / 64 & 1 / 128 & 0 / 1\end{array}$

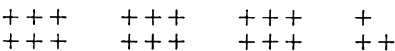

$\begin{array}{lll}++2 & +2 \\ +++ & +\end{array}$

$++++++$

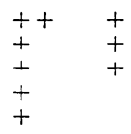


activated papains (Table II). The use of $A B$ serum as a diluent for the anti-D serum prevents these false positive readings. With this diluent and $\mathrm{CDe} / \mathrm{cDE}$ cells the less active papains gave higher titration values than the more active ones, similar to the albumin values. This fact, and Low's finding (1955) that $1 \%$ papain gave stronger agglutination in routine rhesus grouping than $3 \%$ or $5 \%$, suggested the possibility of optimum papain: anti-D proportions. These were the subject of experiment 3 .

\section{EXPERIMENT 3}

Dilutions of papain in saline were tested with dilutions of anti-D in saline and $A B$ serum, using group $O$ $\mathrm{CDe} / \mathrm{cDE}$ cells. This technique, which we called the crosstitration technique, was devised to test the activity of each preparation at different dilutions.

REAGENTS The same reagents were used as in experiment 2.

METHOD Serial dilutions of each papain were made in saline, and of anti-D in saline and in AB serum. One volume of each dilution of the papain was added to one volume of each of the dilutions of anti-D. Two volumes of cells ( $\mathrm{GpO} \mathrm{CDe} / \mathrm{cDE}$ ) were added to each mixture. To avoid timing errors in reading, pairs of rows were set up at 10-minute intervals, incubated for one hour, and read.

RESULTS The results in Table III show the limits of positive activity and the activity of each papain at any given dilution with a given titre of anti-D.

By analogy with Table II false positives are seen at high dilutions of anti-D in saline and are eliminated with $A B$ serum. With the latter the limits of positive activity are clearly defined and are evidence for the existence of optimal proportions of papain to anti-D. Thus at high dilutions of the more active papains dilution of the anti-D produces extension of positive activity, and the albumin titre of the anti-D records positive activity with the most active papains only when they have undergone a degree of dilution beyond which negative activity is again recorded.
In those cross-titrations in which sufficient positive results are present a core of strong positives is seen directed downwards and to the right. This gradient expresses the finding that, within limits, the weaker the papain the weaker the anti-D needs to be to achieve maximal agglutination. Conversely, the stronger the papain activity the stronger the anti-D required. In short, optimal proportions of enzyme to anti-D exist.

\section{EXPERIMENTS 4 AND 5}

The influence of serum in preventing false positives suggested two further experiments. In experiment 4 seven sera were selected at random and serially diluted. One volume of each at each dilution was mixed with 3 volumes of an activated papain. One volume of each mixture was then mixed with one volume of group A cde/cde cells.

The results show that a significant safety margin appeared to exist in the sera tested (Table IV).

In experiment 5 the practice of using enzyme-serum mixtures exceeding 1:1 was tested in series up to 20:1 for each papain with group $\mathrm{O}$ cde/cde and $\mathrm{CDe} / \mathrm{cDE}$ cells.

The results (Table V) show false positives occurring with activated papains at and above 10:1 but no false negatives were apparent.

\section{DISCUSSION}

Table I demonstrates that marked differences exist in commercial preparations of papain. Activation raises enzyme activity and increases the danger of false positives but this danger does not appear to be evident, provided that $\mathrm{AB}$ serum is always used when diluting anti-D and enzyme-serum ratios of the order of $1: 1$ are used.

The cross-titration technique facilitates the assessment of a papain product being used with high-titre anti-D serum for cell grouping and to determine the optimum concentrations for both papain and anti-D

TABLE IV

\begin{tabular}{|c|c|c|c|c|c|c|c|c|c|c|c|c|c|}
\hline \multirow[b]{2}{*}{ Serum in Saline } & \multirow[b]{2}{*}{$1 / 1$} & \multirow[b]{2}{*}{$1 / 2$} & \multirow[b]{2}{*}{$1 / 4$} & \multicolumn{2}{|c|}{ RESULTS IN } & \multicolumn{2}{|c|}{ EXPERIMENT 4} & \multirow[b]{2}{*}{$1 / 128$} & \multirow[b]{2}{*}{$1 / 256$} & \multirow[b]{2}{*}{$1 / 512$} & \multirow[b]{2}{*}{$1 ! 1024$} & \multirow[b]{2}{*}{$1 / 2048$} & \multirow[b]{2}{*}{$0 / 1$} \\
\hline & & & & $1 / 8$ & $1 / 16$ & $1 / 32$ & $1 ! 64$ & & & & & & \\
\hline $\begin{array}{l}\text { AB serum (1) } \\
\text { AB serum (2) } \\
\text { Incomplete anti-D }(C+B) \\
\text { Incomplete anti-D (Marshall) } \\
\text { Incomplete anti-D }(186) \\
\text { Incomplete anti-D }(D+T) \\
\text { Saline anti-D (B.R. 68) }\end{array}$ & & & & & & $\begin{array}{l}+ \\
+\end{array}$ & $\begin{array}{l}+ \\
+\end{array}$ & $\begin{array}{l}++ \\
+ \\
+ \\
+ \\
+ \\
+\end{array}$ & $\begin{array}{l}++ \\
+ \\
+ \\
+ \\
+ \\
+ \\
+\end{array}$ & $\begin{array}{l}++ \\
++ \\
++ \\
++ \\
+ \\
+ \\
+\end{array}$ & $\begin{array}{l}++ \\
++ \\
++ \\
++ \\
++ \\
++ \\
+\end{array}$ & $\begin{array}{l}++ \\
++ \\
++ \\
++ \\
++ \\
++ \\
++\end{array}$ & $\begin{array}{l}++ \\
++ \\
++ \\
++ \\
++ \\
++\end{array}$ \\
\hline
\end{tabular}

Papain: B.D.H. activated cells cde/cde, E/S ratio $=3: 1, \mathrm{E} / \mathrm{S}$ mixture: cells $=1: 1$ 
TABLE V

RESULTS IN EXPERIMENT 5

\begin{tabular}{llllllllll} 
Papain: Serum & $1: 1$ & $2: 1$ & $3: 1$ & $4: 1$ & $5: 1$ & $10: 1$ & $20: 1$ & $1: 0$ & $0: 1$ \\
\hline $\begin{array}{l}\text { 'Final Concentration } 0.25 \\
\text { of Papain (\%) }\end{array}$ & 0.33 & 0.37 & 0.40 & 0.42 & 0.46 & 0.48 & 0.50 & 0.00 \\
\hline $\begin{array}{l}\text { IFinal Titre } \\
\text { of Serum }\end{array}$ & $1 / 4$ & $1 / 6$ & $1 / 8$ & $1 / 10$ & $1 / 12$ & $1 / 22$ & $1 / 42$ & $0 / 1$ & $1 / 2$
\end{tabular}

\begin{tabular}{|c|c|c|c|c|c|c|c|c|c|}
\hline $\begin{array}{l}\text { Cells cde/cde } \\
\text { B.D.H. }\end{array}$ & $\begin{array}{l}\text { Activated } \\
\text { Not activated }\end{array}$ & & & & & & + & ++ & $\begin{array}{l}++ \\
++\end{array}$ \\
\hline Hopkin and Williams & $\begin{array}{l}\text { Activated } \\
\text { Not activated }\end{array}$ & & & & & & + & ++ & $\begin{array}{l}++ \\
++\end{array}$ \\
\hline Merck & $\begin{array}{l}\text { Activated } \\
\text { Not activated }\end{array}$ & & & & & & + & ++ & $\begin{array}{l}++ \\
+\end{array}$ \\
\hline $\begin{array}{l}\text { Cells CDe/cDE } \\
\text { B.D.H. }\end{array}$ & $\begin{array}{l}\text { Activated } \\
\text { Not activated }\end{array}$ & $\begin{array}{l}+t+ \\
+t+\end{array}$ & $\begin{array}{l}+t+ \\
+t+\end{array}$ & $\begin{array}{l}+t \\
+t+\end{array}$ & $\begin{array}{l}++ \\
++\end{array}$ & $\begin{array}{l}++ \\
++\end{array}$ & $\begin{array}{l}++ \\
++\end{array}$ & $\begin{array}{l}++ \\
+\end{array}$ & $\begin{array}{l}++ \\
++\end{array}$ \\
\hline Hopkin and Williams & $\begin{array}{l}\text { Activated } \\
\text { Not activated }\end{array}$ & $\begin{array}{l}++t \\
++t\end{array}$ & $\begin{array}{l}+++ \\
++t\end{array}$ & $\begin{array}{l}++t \\
++\end{array}$ & $\begin{array}{l}++t \\
t+\end{array}$ & $\begin{array}{l}++ \\
++\end{array}$ & $\begin{array}{l}++ \\
++\end{array}$ & $\begin{array}{l}++ \\
+\end{array}$ & $\begin{array}{l}++ \\
++\end{array}$ \\
\hline Merck & $\begin{array}{l}\text { Activated } \\
\text { Not activated }\end{array}$ & $\begin{array}{l}+++ \\
+++\end{array}$ & $\begin{array}{l}++t \\
+++\end{array}$ & $\begin{array}{l}++t \\
+++\end{array}$ & $\begin{array}{l}++t \\
++t\end{array}$ & $\begin{array}{l}+t \\
+t\end{array}$ & $\begin{array}{l}++ \\
++\end{array}$ & $\begin{array}{l}++ \\
+\end{array}$ & $\begin{array}{l}++ \\
++\end{array}$ \\
\hline
\end{tabular}

$\mathrm{E} / \mathrm{S}$ ratio as shown, E/S mixture: cells $=1: 1 .{ }^{1}$ After addition of Cells.

in the mixture. If the activity of the papain is shown to be too low it can be raised by activation, increasing the enzyme-serum ratio, or increasing the initial concentration of papain. The last now seems preferable. A further cross-titration is then necessary to eliminate guesswork in determining the optimal concentrations for maximal agglutination. It might help in selecting the initial concentration if all manufacturers would state the activity of their products (Tribeldi, 1958).

We wish to thank the Director-General of Medical Services, Royal Air Force, and Dr. R. C. Wofinden for permission to publish.

We thank Air Commodore W. P. Stamm, C.B.E., Wing Commander R. M. Cross, M.B., and Dr. D. M. Parkin, of the Blood Group Reference Laboratory, for their help in the conduct of this investigation; Messrs. British Drug Houses Limited, Messrs. Hopkin and Williams Limited, Messrs. E. Merck and their U.K. distributors, and Messrs. Andermann \& Co., for their helpful cooperation, and Junior Technician K. Garvey for his technical assistance.

\section{REFERENCES}

Balls, A. K., and Hoover, S. R. (1937). J. biol. Chem., 121, 737.

Culling, C. F. A. (1957). Handbook of Histopathological Technique, Butterworth, p. 145.

Dunsford, L., and Bowley, C. C. (1955). Techniques in Blood Grouping, Oliver and Boyd, p. 102.

Low, B. (1955). Vox Sanguinis, 5, 94.

Tribeldi (1958). J. Ind. med. Ass., 30, 4, 113.
The papain products used were British Drug Houses papain (batch no. 34577) Hopkin and Williams papain 6458 (batch no. 99961), and Merck Papayotimum 1:100 (7145, batch no. 617630).

Papain, 2.5 g., was ground with $20 \mathrm{ml}$. of Sörensen buffer at $p \mathrm{H} 5.6$ (Culling, 1957) for 15 minutes, washed into a beaker with $200 \mathrm{ml}$. of buffer, and left to stand for 24 hours at $4^{\circ} \mathrm{C}$. Three preparations of each product were made up in this way and then filtered twice. During filtration $100 \mathrm{ml}$. of $1.0 \mathrm{M} \mathrm{L}+$ cystein hydrochloride (Hopkin and Williams 3595 batch no. 90616) was prepared, and $6.25 \mathrm{ml}$. neutralized with an equivalent volume of $\mathrm{N} / \mathrm{I}$ sodium hydroxide. The volume was adjusted to $12.5 \mathrm{ml}$. with buffer for use as activator. Neutral activator, $12.5 \mathrm{ml}$., was added to one preparation of each product and the volume of each adjusted to $250 \mathrm{ml}$. with buffer. Each preparation was then heated to $37^{\circ} \mathrm{C}$., incubated at this temperature for one hour, bottled in $3 \mathrm{ml}$. volumes in sterile bijou bottles as activated papain, and stored at $-20^{\circ} \mathrm{C}$. The second and third preparations of each product were made up and treated in the same manner, except that in the second cystein was omitted and in the third cystein and incubation were omitted. The second preparations were used as control papains, giving results throughout identical to the third non-activated preparations, so proving that incubation without the addition of cystein had no effect. The results of the second group are therefore omitted here.

No sample was used later than eight weeks after preparation and no deterioration of activity was observed during this period. Each $3 \mathrm{ml}$. sample was thawed once only for use and then discarded. 